\title{
Structural behavior of axially loaded precast foamed concrete sandwich panels
}

\begin{abstract}
This paper presents results from an experimental and analytical study of precast foamed concrete sandwich panels (PFCSPs). Full-scale experimental tests of six PFCSPs were conducted to study the behavior of the panels under axial loads. Foamed concrete (FC) was used to cast PFCSP concrete wythes. The axial load-bearing capacity, loadï deflection profiles, loadï strain relationships, slenderness ratio, loadï displacement, loadï deformation, failure and collapse modes, cracking patterns, and propagations under constant increments of axial loads were recorded and discussed. The properties and use of FC were briefly reviewed. Results of the experimental test and finite element analysis were compared with the theoretical values calculated based on the American Concrete Institute (ACI) design equation for a solid concrete wall and other empirical formulas developed by antecedent researchers which might be applicable to predict the ultimate load-bearing capacity of sandwich panels. A semi-empirical formula was proposed based on the laboratory test and finite element analysis results.
\end{abstract}

Keyword: Precast foamed concrete sandwich panel (PFCSP); Foamed concrete (FC); Finite element model (FEM) analysis; Slenderness ratio; Ultimate strength capacity; Structural reinforced sandwich wall 